\title{
Cross-Sectional Study on Prevalence of Middle East Respiratory Syndrome Coronavirus (MERS-CoV) Specific RNA and Anti-MERS-RBD in Camel Milk from Different Regions of Saudi Arabia
}

Aiydh Alshehri ( $\nabla$ aa2446@hotmail.com )

Riyadh Municipality Central Arae Labs https://orcid.org/0000-0003-0495-3549

Mir Naiman Ali

Riyadh Municipality Central Area Labs

Nabil Miled

University of Jeddah

\section{Research}

Keywords: Camel milk, Saudi Arabia, MERS-CoV, Viral RNA, IgG, Receptor-Binding Protein.

Posted Date: July 8th, 2021

DOI: https://doi.org/10.21203/rs.3.rs-634577/v1

License: (1) (1) This work is licensed under a Creative Commons Attribution 4.0 International License. Read Full License 


\section{Abstract}

Background:

Middle East respiratory syndrome coronavirus (MERS-CoV) causes viral pneumonia disease in humans. The close contact with camels and drinking milk may cause Middle East respiratory syndrome coronavirus transfer to humans.

Methods:

This study was designed to detect the existence of Middle East respiratory syndrome coronavirus in camel milk samples collected from healthy animals according to local customs from 83 barns located around Saudi Arabia. Camel milk samples were examined for viral RNA by RT-qPCR, also ELISA assay was performed to detect IgG antibodies directed against MERS Receptor-Binding Protein (RBD).

Results:

Among 83 camel milk samples tested,the result showed that seven samples (8.4\%) were positive for MERSCoV RNA, while $40.9 \%$ of camel milk samples had antibodies directed against this virus.

Conclusions:

The findings indicate that some regions (East and South part) are characterized by a high incidence of viral antibodies. The South western region displayed the lowest infection rates. Camel breed Sahilia seems to be resistant to viral infection as compared to other breeds such as Hamra. This need to be more explored in order to reduce spread of infection and also to understand the underlying reasons. The presence of viral RNA in camel milk samples warrants for measures to prevent possible food-borne transmission of Middle East respiratory syndrome coronavirus through milk consumption.

\section{Introduction}

The Middle East respiratory syndrome coronavirus (MERS-CoV) was first detected in 2012 in Saudi Arabia[1]. It is characterized by severe viral pneumonia leading to death. By the end of May 2021, a total of 2574 laboratory-confirmed cases of Middle East respiratory syndrome (MERS), including 886 associated deaths (case-fatality ratio $34.4 \%$ ) were reported globally[2]. MERS-CoV is an enveloped virus with a nucleocapsid of helical symmetry. It was previously known as Novel coronavirus 2012 and HCoV-EMC[3]. Domestic animals and wildlife may be an important cause of viral infection. Dromedary camels were the only species from which antibodies specific to MERS-CoV have been detected after many seroepidemiological studies on camels, cattle, sheep, goats, horses and poultry in the Arabian Peninsula and the Middle East[4]-[8].Serological evidence of infection of dromedaries from the Arabian Peninsula (Saudi Arabia, United Arab Emirates (UAE), Oman, Qatar and Jordan) by MERS-CoV has been reported with a seroprevalence in adult animals generally being $>90 \%$. Moreover, serological evidence of dromedaries infections in Africa (Egypt, Ethiopia, Nigeria, Tunisia, Sudan and the Canary Islands) were also reported 
with a similarly high sero-prevalence except Tunisia and Canary Islands, where adult sero-prevalence were only $54 \%$ and $14 \%$, respectively[5], [9], [10]. The adult animal sero-prevalence was generally higher than in juveniles. MERS-CoV viral RNA was detected by nasal swabs of dromedaries from Qatar, Oman, Saudi Arabia, Egypt and UAE[11]-[17].

Infection by MERS-CoV in the Kingdom of Saudi Arabia and UAE occurs often during winter and spring[18], [19]. From thirty to fifty cases are reported every year in the Middle East[20]. MERS-CoV may be transferred and amplified depending on the regular movement of camels that crosses the borders of many countries. The camel movement in the Arabian Peninsula may play an important role in MERS-CoV spreading during this period. Milk is used as a main meal by the Bedouins who live in the desert. The use of this meal extends for several days or months.

The consumption of raw milk is mainly due to the widespread belief that camel milk has preventive and curative properties against many diseases and that boiling milk destroys its nutritional and medicinal value[21]. Consumption of raw non-pasteurized milk has been proposed as a source of infection in one human MERS case[22], [23]. In a study that reported the discovery of MERS-CoV RNA in camel milk[24], it was not known whether the milk was contaminated or the udder was infected by the regular spread of the virus through the bloodstream. Regardless of the ways the virus can enter to milk, these facts support the possibility that raw camel milk can be a source of infection with the MERS-CoV. Hence the present study was undertaken to screen the presence of MERS-CoV RNA and Anti-MERS-RBD antibodies in camel milk samples.

\section{Materials And Methods}

\subsection{Collection of milk samples}

MERS coronavirus (MERS-CoV) that emerged in 2012 in the Arabic peninsula, continues to be a risk and threat for Human health. Few reports have described possible contamination through camels. Very little is known about the potency of camel milk to bear the virus. In order to increase the awareness about raw camel milk as a possible virus vector.

Camel milk samples were collected during the period from May to July 2020 from 83 Arabian camels in different barns from different cities located around the Kingdom of Saudi Arabia (Fig. 1). Samples were collected from camels belonging to four main breeds: Majhim, Maghater, Hamra and Sahilia (Fig. 2)[25]at different ages. Majhim is black coated with a pointed hump long hair covering the body and long legs. They are originated from north-eastern part of the country and are the best dairy producers of the Kingdom. Hamra is medium size dairy breed with a clear brown coat color. Maghater have a white-yellow coat color. They have pointed ears and low pilosity. Sahilia live along the Red Sea coast and have a red coat color, a small head with a pronounced forehead (Fig. 2).

Healthy Camels only were chosen for this experiment as camels showing clinical signs of any disease were excluded from this study. The milk samples were collected by the camel owner or handler according to 
regional customs after doing all hygienic measures. Camels were milked and milk was placed in DNA and RNA free cans. All samples were stored at $4^{\circ} \mathrm{C}$ until transfer to the laboratory in ice boxes.

\subsection{RNA extraction and RT-qPCR for detection of MERS-CoV RNA}

RNA was extracted from camel milk samples, according to manufacturer's instructions using Fast RNATM ProBlue Kit (MP Biomedicals- China). Prevalence of MERS-CoV in camel milk samples was assessed by RTqPCR using specific probes for the RNA virus. MERS-CoV primers used for the specific and exclusive in vitro quantification of the coronavirus isolates were designed based on sequences for the EMC strain by targeting the upE regions of ORF5 and the ORF1ab regions[26]-[28]. In short, 5 ul of extracted RNA was transferred to RT-qPCR using UpE primers, whereas was performed using the Human Coronavirus 2012 (MERS) (GENESIG, Primer design Ltd, UK) kit according to the manufacturer's protocol. All samples were run in 48 well reaction plate by PROPLATE48 and analyzed using Prime Pro 48 RT-qPCR system (TECHNE version 5.2.15.0) (Stone, Staffordshire, UK). The reaction conditions were as follow: $55^{\circ} \mathrm{C}$ for $10 \mathrm{~min}$ (reverse transcription), $95^{\circ} \mathrm{C}$ for $2 \mathrm{~min}$ (enzyme activation), $95^{\circ} \mathrm{C}$ for $10 \mathrm{sec}$ (denaturation), and $60^{\circ} \mathrm{C}$ for 1 min for 50 cycles (amplification).

\subsection{Anti-MERS-RBD ELISA}

The presence of antibodies against the MERS receptor binding protein (RBD) in camel milk samples was detected using an Anti-MERS-RBD IgG ELISA kit (Alpha Diagnostic International, Texas, USA). The kit is an indirect ELISA used for the detection and quantification of IgG antibodies directed against MERS-CoV RBD. The ELISA assay was carried out following the manufacturer instructions. Assay steps were performed at room temperature[29],[30]. In brief, the milk samples were diluted 1:100 in sample diluent to reduce nonspecific binding; the diluted samples were incubated in wells coated with the purified S1-RBD antigen of MERS coronavirus (MERS-CoV S1). In the case of positive samples, the specific antibodies will bind MERS antigens. A second incubation is carried out by an enzyme-labeled Anti-camel IgG HRP (peroxidase conjugate) stimulating the reaction to detect the bound antibodies. The substrate is then added and its product is detected by fluorescence. The results were read on microplate reader (Randox ELx800, UK)

\subsection{Data management and statistical analysis}

Data were collected from RT-qPCR machine as Quantity of viral RNA, and from ELISA reader as OD values. The data was analyzed by the Statistical Package for Social Sciences (SPSS) for Windows version 22.0 (SPSS Inc., Chicago, Illinois).

\section{Results}

\subsection{Milk sample collection}

A risk assessment of presence of viral RNA was carried out in 83 milk samples randomly collected in various regions of Saudi Arabia. Due to the lack of risk assessment and the belief that heating would 
destroy milk benefits, these small farms can be an important hazard for the spread of virus through manipulation and consumption of crude milk.

In total, 83 milk samples were collected from rural small camel farms spread all over Saudi Arabia, except the northern region where camel farming is less. Collection area was geographically divided to four main regions in Saudi Arabia: 22 samples from Central region (Riyadh, Qassim and Hail), 24 form Western region (Madina, Jeddah, Al Taif and Makkah), 20 from South western region (AlBaha, 'Asir and Jazan) and 17 from the East and South region (Eastern province and Najran) (Fig. 3). Young camels aged between 3 and 5 years were 41 and animals older than 6 were 42. Depending on the region, some camel breeds are more frequent than others. The breeds of camels used in this study are Majhim (28), Hamra (17), Maghatir (22) and Sahilia (16) (Fig. 1).

\subsection{Detection and quantification of MERS-CoV RNA in camel milk samples by RT-qPCR}

Among 83 milk samples tested, only 7 camel milk samples (8.4\%) contained MERS-CoV RNA as detected by real time qPCR assays. These positive samples were as follows: 2/22 in Central region (Riyadh, Qassim, and Hail), 4/17 in East and South region (Najran and Eastern province), and 1/24 in West region (AlTaif, Jeddah, Makkah, and Madina). Meanwhile, MERS-CoV RNA was not detected in 20 camel milk samples collected in the South western region (Jazan, Asir, and AlBaha) (Table 1). 
Table 1

The existence of MERS-CoV RNA in camel milk samples from different regions, type, and ages in Saudi Arabia.

\begin{tabular}{|c|c|c|c|c|c|c|}
\hline & $\begin{array}{l}\text { No of } \\
\text { tested milk } \\
\text { samples }\end{array}$ & $\begin{array}{l}\text { No of } \\
\text { Positive } \\
\text { milk } \\
\text { samples }\end{array}$ & $\begin{array}{l}\text { Percentage } \\
\text { of positivity }\end{array}$ & $\begin{array}{l}\text { Quantity of } \\
\text { MERS-CoV RNA } \\
\text { (copies/ul) }\end{array}$ & $X^{2}$ test & P-value \\
\hline Region & & & & & 0.00257 & 0.011887 \\
\hline Central & 22 & 2 & $9.09 \%$ & $12.88^{\mathrm{a}}, 1.331^{\mathrm{b}}$ & & \\
\hline East and & 17 & 4 & $23.5 \%$ & $64.30^{\mathrm{a}}, 4.992^{\mathrm{a}}$ & & \\
\hline South & 20 & 0 & $0 \%$ & $82.98^{a}, 1.173^{b}$ & & \\
\hline western & 24 & 1 & $4.16 \%$ & & & \\
\hline West & & & & $4612893^{c}$. & & \\
\hline $\begin{array}{l}\text { Type of } \\
\text { camel }\end{array}$ & & & & & 0.001066 & 0.008606 \\
\hline breed & 28 & 3 & $10.71 \%$ & $4.992^{a}, 82.98^{a}$ & & \\
\hline Majhim & 17 & 2 & $11.76 \%$ & $12.88^{\mathrm{a}}$ & & \\
\hline Hamra & 22 & 2 & $9.09 \%$ & $4612893^{c}$ & & \\
\hline Maghatir & 16 & 0 & $0 \%$ & 1.17 & & \\
\hline Sahilia & & & & $64.30^{\mathrm{a}}, 1.331^{\mathrm{b}}$. & & \\
\hline Age & & & & & 0.002055 & 0.066767 \\
\hline $3-5$ years & 42 & 4 & $9.5 \%$ & $64.30^{\mathrm{a}}, 4.992^{\mathrm{a}}$ & & \\
\hline 6 years $\geq$ & 41 & 3 & $7.3 \%$ & $82.98^{a}, 1.331^{b}$ & & \\
\hline & & & & $\begin{array}{l}4612893^{\mathrm{c}} \\
1.173^{\mathrm{b}}, 12.88^{\mathrm{a}} .\end{array}$ & & \\
\hline
\end{tabular}

a Between the standard dilutions.

${ }^{\mathrm{b}}$ Less than standard dilutions.

${ }^{c}$ Higher than standard dilutions.

The percentage of positivity for detection of MERS-CoV RNA was $10.71 \%$ in Majhim, $11.76 \%$ in Hamra and 9.09\% in Maghatir breeds of camels. However, there were no viral detection among Sahilia breed samples. This breed is mainly located in South Western region. With respect to age of the camels, the percentage of positivity was 9.5 and $7.3 \%$ for camels aged from $3-5$ years and 6 years respectively. (Table 1 ).

The data for quantitative RT-qPCR revealed following findings- 4 out of 7 positive samples (Sample-19, 20, 22 and 56) displayed RNA quantity in the range of standard dilutions. Higher concentration of RNA was detected in sample 32 which was more than standard dilutions, whereas two samples 53 and 61 has 
shown lower RNA concentration than the standard dilutions (Table 1). The remaining samples were negative for MERS-CoV RNA.

\subsection{Detection and quantification of MERS-CoV IgG antibodies via Anti-MERS Receptor-Binding protein (RBD) ELISA}

According to 83 camel milk samples were collected from different barns in different regions of Saudi Arabia. The ELISA assay was used to check the presence of Anti-MERS-RBD IgG in milk samples. AntiMERS-RBD IgG was detected in 34 camel milk samples (40.9\%). Prevalence of antibodies was high in East and South region (Najran and Eastern province) $(76.47 \%$ ) followed by West region (AlTaif, Jeddah, Makkah, and Madina) (50\%). However, these percentages were lower in Central region (Riyadh, Qassim, and Hail) (27.27\%) and Western south region (Jazan, Asir, and AlBaha) (15\%) (Table 2). Detection pattern of AntiMERS-CoV antibodies displayed similar tendency to the presence of viral RNA. The East and South region displayed the highest yields and the South western the lowest (Table 2). 
Table 2

Detection of MERS-CoV IgG Anti-MERS-RBD in camel milk samples from different regions, type, and ages in Saudi Arabia.

\begin{tabular}{|c|c|c|c|c|c|c|}
\hline & $\begin{array}{l}\text { No of } \\
\text { tested } \\
\text { milk } \\
\text { samples }\end{array}$ & $\begin{array}{l}\text { No of } \\
\text { Positive } \\
\text { samples }\end{array}$ & $\begin{array}{l}\text { Percentage } \\
\text { of positivity }\end{array}$ & $\begin{array}{l}\text { Concentration of } \\
\text { Anti-MERS-RBD lgG } \\
\text { antibodies (U/ml) }\end{array}$ & $X^{2}$ test & $P$-value \\
\hline \multicolumn{5}{|l|}{ Region } & \multirow[t]{6}{*}{$\begin{array}{l}1.76935 \mathrm{E}- \\
07\end{array}$} & \multirow[t]{6}{*}{0.001342} \\
\hline Central & 22 & 6 & $27.27 \%$ & $1.18-1.77$ & & \\
\hline \multirow{2}{*}{$\begin{array}{l}\text { East and } \\
\text { South }\end{array}$} & 17 & 13 & $76.47 \%$ & $1.078-2.308$ & & \\
\hline & 20 & 3 & $15 \%$ & $1.27-1.29$ & & \\
\hline \multirow{2}{*}{$\begin{array}{l}\text { South } \\
\text { western } \\
\text { West }\end{array}$} & 24 & 12 & $50 \%$ & $1.042-2.07$ & & \\
\hline & & & & & & \\
\hline \multirow{2}{*}{$\begin{array}{l}\text { Type of } \\
\text { camel } \\
\text { breed }\end{array}$} & & & & & \multirow[t]{6}{*}{$\begin{array}{l}1.76935 \mathrm{E}- \\
07\end{array}$} & \multirow[t]{6}{*}{0.000464} \\
\hline & 28 & 13 & $46.42 \%$ & $1.042-2.001$ & & \\
\hline Majhim & 17 & 11 & $64.7 \%$ & $1.041-2.308$ & & \\
\hline Hamra & 22 & 8 & $36.36 \%$ & $1.029-2.193$ & & \\
\hline Maghatir & 16 & 2 & $12.5 \%$ & $1.182-1.322$ & & \\
\hline \multicolumn{5}{|l|}{ Sahilia } & & \\
\hline \multicolumn{2}{|l|}{ Age } & & & & \multirow{3}{*}{$\begin{array}{l}2.30164 \mathrm{E}- \\
09\end{array}$} & \multirow[t]{3}{*}{0.000784} \\
\hline \multirow{2}{*}{$\begin{array}{l}3-5 \\
\text { years } \\
6 \text { years } \geq\end{array}$} & 42 & 15 & $35.7 \%$ & $1.078-2.193$ & & \\
\hline & 41 & 19 & $46.34 \%$ & $1.029-2.308$ & & \\
\hline
\end{tabular}

Among 34 Anti-MERS-RBD IgG positive milk samples (40.96\%), only 5 displayed an antibody concentration higher than $2 \mathrm{U} / \mathrm{ml}$. It is noteworthy that camel milk samples displaying the highest antibody yields (ranging from 1.04 to $2.3 \mathrm{U} / \mathrm{ml}$ ) correspond to high viral incidence regions: East and South region and Western region. The low antibody incidence regions (the Western and Central regions) displayed the lowest antibody concentrations (from 1.18 to $1.77 \mathrm{U} / \mathrm{ml}$ ) (Table 2).

Prevalence depending on the camel breed showed that Hamra (64.7\%), and Majhim (46.42\%) types displayed the highest positivity rates for Anti-MERS-RBD IgG followed by Maghatir (36.36\%), then Sahilia (12.5\%) types. The prevalence tendency of Anti-MERS-Cov IgG in camel milk samples of different camel breeds was similar to that of viral RNA. This shows that Hamra and Majhim breeds are mostly exposed to MERS-CoV infection likely due to their location in the high camel traffic East and South region. The Sahilia breed localized in the Western region seems to be more resistant to viral infection (Table 2).

The percentage of positivity for Anti-MERS-RBD IgG in older camels ( $\geq 6$ years, $46.34 \%$ ) was higher than in (3-5 years) camels (35.7\%) (Table 2). This is likely due to the camels' history in being exposed to the virus 
for longer time.

Upon comparison of results of RT-qPCR with ELISA assay it was observed that among the 34 camel milk samples which were positive for Anti-MERS-RBD IgG antibodies, only 4 contained MERS-CoV RNA (Table 3). It was also noticed that 3 milk samples that were positive for MERS-CoV RNA did not show AntiMERS-RBD IgG antibodies (Table 3).

Table 3

Comparison of detected positive samples RNA for MERS-CoV by RT-qPCR with Anti-MERS-RBD by ELISA assay.

\begin{tabular}{|lllll|}
\hline $\begin{array}{l}\text { No } \\
\text { sample }\end{array}$ & \multicolumn{2}{l}{ RT-qPCR } & \multicolumn{3}{l|}{ ELISA assay } \\
\cline { 2 - 5 } & $\begin{array}{l}\text { MERS- } \\
\text { CoV }\end{array}$ & $\begin{array}{l}\text { Quantify of MERS-CoV RNA } \\
\text { (copies/ul) }\end{array}$ & $\begin{array}{l}\text { Anti-MERS- } \\
\text { RBD }\end{array}$ & $\begin{array}{l}\text { Quantify of IgG } \\
\text { (U/ml) }\end{array}$ \\
\hline $\begin{array}{l}\text { Sample } \\
\mathbf{1 9}\end{array}$ & + & 64.30 & + & 2.193 \\
$\begin{array}{l}\text { Sample } \\
\mathbf{2 0}\end{array}$ & + & 4.992 & - & 0.453 \\
$\begin{array}{l}\text { Sample } \\
\mathbf{2 2}\end{array}$ & + & 82.98 & + & 1.631 \\
$\begin{array}{l}\text { Sample } \\
\mathbf{3 2}\end{array}$ & + & 4612893 & + & 2.07 \\
\hline $\begin{array}{l}\text { Sample } \\
\mathbf{5 3}\end{array}$ & + & 1.173 & + & 1.212 \\
\hline $\begin{array}{l}\text { Sample } \\
\mathbf{5 6}\end{array}$ & + & 12.88 & + & 0.9 \\
\hline $\begin{array}{l}\text { Sample } \\
\mathbf{6 1}\end{array}$ & + & 1.331 & - & 0.417 \\
\hline
\end{tabular}

\section{Discussion}

In earlier studies detection of MERS-CoV in archived serum samples showed a high serum prevalence of MERS-CoV in the tested specimens, which appeared in the 1990s[7], [31]. Consequently, it may indicate the possibility of the circulation of MERS-CoV in dromedary camels before its actual appearance in human as it was first announced in 2012[1].

Epidemiological investigations were conducted by May 20, 2018 for all 333 notifications of MERS-CoV patients until December 6, 2020 in the Saudi Arabia issued by Ministry of Health (MOH), 92 of them related to camels, while the number of deaths reached 90 cases. In fact, the World Health Organization (WHO) reported 5 cases of people infected by drinking camel milk in February and April 2020. Among them there were 3 live cases, and 2 died. 
For thousands of years, human have consumed raw milk from the dromedary camel. It is believed that raw milk has healing properties when it is drunk hot "without sterilization" directly from the udder[32]. Whereas at the present time, many arid countries, especially in rural areas, are still consuming dromedary camel milk without sterilization, such as Saudi Arabia, the Arabian Gulf and other countries in the Middle East and countries from Africa[33].

The camel milk samples which were broadly collected from various regions of Saudi Arabia included East and South, West, South western, and Central regions. The milk samples were collected in the traditional way used by ordinary people to be more accurate in detecting camel milk contamination potential. In this study, RNA of MERS-CoV was detected in 7 samples out of 83 (8.4\%) via RT-qPCR assays. Among the seven infected samples, 4 only contained Anti-MERS-RBD antibodies. The corresponding camels are infected with the virus without displaying any symptoms. The remaining 3 samples did not contain AntiMERS-RBD antibodies. This might be explained by the fact that the animals are in the first infection stages. The simultaneous detection of viral RNA and antibodies to MERS-CoV in camel milk samples observed in the present study is in agreement with reports[34] on the prevalence of MERS-CoV RNA (38.6\%) and high seropositivity (70.8\%) in slaughtered camels of Riyadh, Saudi Arabia. Camel milk samples containing AntiMERS-RBD IgG without the presence of RNA are indicative of previous exposure to the virus.

The prevalence of MERS-CoV RNA in different regions of Saudi Arabia varied from 23.5\% in East and South to $0 \%$ in South western. The East and South region seems to display a high positivity rate. This might be explained by the high frequency of camel transport in the region[35]. This is in line with reports of camel swab contaminations in UAE being the highest at the Saudi border[36]. This study revealed that 3-5years aged camels had high prevalence of MERS-CoV RNA $(9.5 \%)$ than $\geq 6$ years $(7.3 \%)(P<0.01)$. However, camels of $\geq 6$ years showed high positivity to Anti-MERS-RBD antibody (46.34\%) when compared with camels of 3-5 years (35.7\%). Several previous studies have reported high seropositivity and high infection rate in adult camels compared to juvenile[35], [37]. Additionally, Hamra camel breed showed highest positivity of $11.76 \%$ to MERS-CoV RNA than Majhim (10.71\%), Maghatir $(9.09 \%)$ and Sahilia breeds (0\%) $(\mathrm{P}<0.01)$. Hence, the highest positivity to both RNA and antibodies to MERS-CoV was recorded in Hamra breed and lowest positivity was recorded in Sahilia breed. This variation is most likely due to the difference in distribution of these breeds in the various regions. More investigations are needed to explain the possible resistance of Sahilia breed towards MERS-CoV.

The present study showed high prevalence rates of Anti-MERS-RBD-specific IgG antibodies (40.9\%) in dromedary camel milk samples. Most of the earlier reports have shown high seroprevalence rates of MERSCoV antibodies. A MERS-CoV antibodies seroprevalence of $90 \%$ was reported for camels from the North of Mali[38]. Similarly, high seroprevalences of $75.62 \%$ and $46.9 \%$ were reported for camels from Pakistan and Kenya respectively[39], [40]. This work is, to the best of our knowledge, the first to report the prevalence of RNA and antibodies to MERS-CoV in camel milk samples from Saudi Arabia. Detection of MERS-CoV RNA in camel milk samples is in agreement with previous studies on the persistence of RNA positivity for extended period of time in milk and stool in addition to respiratory secretions[9], [14], [17], [41]-[43]. In camel milk samples from a region in Qatar, viral RNA was detected in 5 among 7 samples [9]. The detection of MERS-CoV RNA in camel milk samples ensures that the milk is infectious. This may support 
the proof of transmission of MERS-CoV to the human by drinking raw milk directly without sterilization, however, further in-depth investigations are needed. In addition, it may lead to the possibility of spreading the infection when more than one person drinks camel milk in one bowl. It has been suggested that consuming camel milk containing MERS-CoV may lead to the possibility of infection through introduction to then respiratory tract, as recent data showed that MERS-CoV was introduced experimentally in camel milk can live for up to 72 hours at $4^{\circ} \mathrm{C}$ and $22^{\circ} \mathrm{C}[35]$.

These results indicate the need to focus on the mechanism of MERS-CoV transmission from camel milk to human, as it may be one of the most important mechanisms. Furthermore, determining groups at highest risk for zoonotic MERS-CoV infection could also help to optimize future vaccine trials in geographic region where MERS-CoV is spread. The high prevalence of Anti-MERS-RBD antibodies resulting from previous infections might be a protection for camels against MERS-CoV. Nevertheless, it was reported that prior infection or acquired maternal antibodies might not provide an effective protection from infection[31]. It is noteworthy that the absence of clear symptoms in MERS-CoV infected camels increase their danger in viral transmission.

\section{Conclusion}

Human infection might be acquired by direct contact with infected camels or by drinking raw camel milk. Camel milk samples collected from randomly chosen farms from various regions in Saudi Arabia showed the presence of Anti-MERS-RBD antibodies (40\%) and MERS-CoV RNA (about $8 \%$ ). Consequently, the presence in the Middle East virus in camel milk warrants measures to prevent putative food-borne transmission of MERS-CoV. In order to elucidate the epidemiology of MERS-CoV in Saudi Arabia, further studies are required.

\section{Abbreviations}

MERS, Middle East Respiratory Syndrome; MERS-CoV, Middle East Respiratory Syndrome Coronavirus; RBD, Receptor-Binding Protein; Anti-MERS-RBD, Antibodies for Middle East Respiratory Syndrome Receptor-Binding Protein.

\section{Declarations}

\subsection{Ethical approval}

Jeddah University ethical committees approved the study.

\subsection{Consent for publication}

Not applicable

\subsection{Availability of data and materials}

The data presented in this study are available in the article. 


\subsection{Competing interests}

The authors declare that they have no competing interests.

\subsection{Funding}

No funding sources.

\subsection{Author contributions}

"Conceptualization, M.N.A \& N.M.; Methodology, A.A.; Investigation, A.A.; Data curation, M.N.A.; Writing-original draft preparation, A.A.; Writing-review and editing, M.N.A. \& N.M.; Supervision, N.M. \& N.M.A.; All authors have read and agreed to the published version of the manuscript."

\subsection{Acknowledgments}

The authors would like to thank Jeddah University for approval of this work. The authors thank the people who helped in collection of samples and also thank Riyadh Municipality Central Area Labs, Riyadh for providing necessary facilities to carry out the work.

\section{References}

[1] A. M. Zaki, S. Van Boheemen, T. M. Bestebroer, A. D. M. E. Osterhaus, and R. A. M. Fouchier, "Isolation of a novel coronavirus from a man with pneumonia in Saudi Arabia," N. Engl. J. Med., vol. 367, no. 19, pp. 1814-1820, 2012, doi: https://doi.org/10.1056/NEJMoa1211721.

[2] World Health Organization Regional Office for the Eastern Mediterranean, "Epidemic and pandemic-prone diseases. MERS situation update.," World Health Organization, 2021. http://www.emro.who.int/health-topics/mers-cov/mers-outbreaks.html.

[3] B. Guery et al., "Clinical features and viral diagnosis of two cases of infection with Middle East Respiratory Syndrome coronavirus: a report of nosocomial transmission," Lancet, vol. 381, no. 9885, pp. 2265-2272, 2013, doi: https://doi.org/10.1016/S01406736(13)60982-4.

[4] M. G. Hemida et al., "Middle East Respiratory Syndrome (MERS) coronavirus seroprevalence in domestic livestock in Saudi Arabia, 2010 to 2013," Eurosurveillance, vol. 18, no. 50, p. 20659, 2013, doi: https://doi.org/10.2807/15607917.ES2013.18.50.20659.

[5] R. A. Perera et al., "Seroepidemiology for MERS coronavirus using microneutralisation and pseudoparticle virus neutralisation assays reveal a high prevalence of antibody in dromedary camels in Egypt, June 2013," Eurosurveillance, vol. 18, no. 36, p. 20574, 2013, doi: https://doi.org/10.2807/1560-

7917.ES2013.18.36.20574. 

serology in major livestock species in an affected region in Jordan, June to September 2013," Eurosurveillance, vol. 18, no. 50, p. 20662, 2013, doi: https://doi.org/10.2807/1560-7917.ES2013.18.50.20662.

[7] C. B. E. M. Reusken et al., "Middle East respiratory syndrome coronavirus neutralising serum antibodies in dromedary camels: a comparative serological study," Lancet Infect. Dis., vol. 13, no. 10, pp. 859-866, 2013, doi: https://doi.org/10.1016/S1473-3099(13)70164-6.

[8] B. Meyer, C. Drosten, and M. A. Müller, "Serological assays for emerging coronaviruses: challenges and pitfalls," Virus Res., vol. 194, pp. 175-183, 2014, doi: https://doi.org/10.1016/j.virusres.2014.03.018.

[9] C. B. Reusken et al., "Middle East respiratory syndrome coronavirus (MERS-CoV) RNA and neutralising antibodies in milk collected according to local customs from dromedary camels, Qatar, April 2014," Eurosurveillance, vol. 19, no. 23, p. 20829, 2014, doi: https://doi.org/10.2807/1560-7917.ES2014.19.23.20829.

[10] V. M. Corman et al., "Antibodies against MERS coronavirus in dromedary camels, Kenya, 1992-2013,” Emerg. Infect. Dis., vol. 20, no. 8, pp. 1319-1322, 2014, doi: https://dx.doi.org/10.3201\%2Feid2008.140596.

[11] A. N. Alagaili et al., "Middle East respiratory syndrome coronavirus infection in dromedary camels in Saudi Arabia," MBio, vol. 5, no. 2, 2014, doi: https://doi.org/10.1128/mBio.00884-14.

[12] D. K. W. Chu et al., "MERS coronaviruses in dromedary camels, Egypt," Emerg. Infect. Dis., vol. 20, no. 6, p. 1049, 2014, doi: https://dx.doi.org/10.3201\%2Feid2006.140299.

[13] B. L. Haagmans and A. D. M. E. Osterhaus, "Neutralizing the MERS coronavirus threat," Sci. Transl. Med., vol. 6, no. 235, pp. 235fs19-235fs19, 2014, doi: https://doi.org/10.1126/scitranslmed.3009132.

[14] M. G. Hemida et al., "MERS coronavirus in dromedary camel herd, Saudi Arabia," Emerg. Infect. Dis., vol. 20, no. 7, pp. 1231-1234, 2014, doi: https://dx.doi.org/10.3201\%2Feid2007.140571.

[15] N. Nowotny and J. Kolodziejek, "Middle East respiratory syndrome coronavirus (MERS-CoV) in dromedary camels, Oman, 2013," Eurosurveillance, vol. 19, no. 16, p. 20781, 2014, doi: https://doi.org/10.2807/1560-7917.ES2014.19.16.20781.

[16] V. S. Raj et al., "Isolation of MERS coronavirus from a dromedary camel, Qatar, 2014," Emerg. Infect. Dis., vol. 20, no. 8, p. 1339, 2014, doi: https://dx.doi.org/10.3201\%2Feid2008.140663. 
[17] U. Wernery et al., "Acute middle east respiratory syndrome coronavirus infection in livestock dromedaries, Dubai, 2014," Emerg. Infect. Dis., vol. 21, no. 6, pp. 1019-1022, 2015, doi: https://dx.doi.org/10.3201\%2Feid2106.150038.

[18] I. K. Oboho et al., "2014 MERS-CoV outbreak in Jeddah-a link to health care facilities," N. Engl. J. Med., vol. 372, no. 9, pp. 846-854, 2015, doi: https://doi.org/10.1056/NEJMoa1408636.

[19] M. S. Majumder, C. Rivers, E. Lofgren, and D. Fisman, "Estimation of MERScoronavirus reproductive number and case fatality rate for the spring 2014 Saudi Arabia outbreak: insights from publicly available data," PLoS Curr., vol. 6, 2014, doi: https://dx.doi.org/10.1371\%2Fcurrents.outbreaks.98d2f8f3382d84f390736cd5f5fe133c.

[20] Ministry of Helath, "Report Status," 2020. [Online]. Available: https://www.moh.gov.sa/en/CCC/events/national/Pages/2020.aspx.

[21] S. M. Shamsia, "Nutritional and therapeutic properties of camel and human milks," Int. J. Genet. Mol. Biol., vol. 1, no. 4, pp. 52-58, 2009, [Online]. Available: http://www.academicjournals.org/IJGMB.

[22] Z. A. Memish et al., "Sparse evidence of MERS-C o V infection among animal workers living in S outhern S audi A rabia during 2012," Influenza Other Respi. Viruses, vol. 9, no. 2, pp. 64-67, 2015, doi: https://doi.org/10.1111/irv.12287.

[23] Z. A. Memish et al., "Human Infection with MERS Coronavirus after Exposure to Infected Camels, Saudi Arabia, 2013," Emerg. Infect. Dis., vol. 20, no. 6, pp. 10121015, Jun. 2014, doi: 10.3201/eid2006.140402.

[24] M. G. Hemida, A. Al-Naeem, R. A. P. M. Perera, A. W. H. Chin, L. L. M. Poon, and M. Peiris, "Lack of Middle East Respiratory Syndrome Coronavirus Transmission from Infected Camels," Emerg. Infect. Dis., vol. 21, no. 4, pp. 699-701, Apr. 2015, doi: 10.3201/eid2104.141949.

[25] H. R. Abdallah and B. Faye, "Phenotypic classification of Saudi Arabian camel (Camelus dromedarius) by their body measurements," Emirates J. Food Agric., vol. 24, no. 3, pp. 272-280, 2012, doi: https://dx.doi.org/10.9755/ejfa.v24i3.12011.

[26] V. M. Corman et al., "Assays for laboratory confirmation of novel human coronavirus (hCoV-EMC) infections," Eurosurveillance, vol. 17, no. 49, p. 20334, 2012, [Online]. Available: https://doi.org/10.2807/ese.17.49.20334-en.

[27] V. M. Corman et al., "Detection of a novel human coronavirus by real-time reversetranscription polymerase chain reaction," Eurosurveillance, vol. 17, no. 39, p. 20285, 2012, [Online]. Available: https://doi.org/10.2807/ese.17.39.20285-en.

[28] World Health Organization, "Laboratory testing for Middle East respiratory syndrome coronavirus," WHO, 2013. www.who.int/csr/disease/coronavirusinfections/MERS Lab 
recos 16 Sept 2013.pdf?ua $=1$.

[29] M. A. Müller et al., "MERS Coronavirus Neutralizing Antibodies in Camels, Eastern Africa, 1983-1997," Emerg. Infect. Dis., vol. 20, no. 12, p. 2093, Dec. 2014, doi: 10.3201/eid2012.141026.

[30] H. A. Mohd, J. A. Al-Tawfiq, and Z. A. Memish, "Middle East Respiratory Syndrome Coronavirus (MERS-CoV) origin and animal reservoir," Virol. J., vol. 13, no. 1, p. 87, Dec. 2016, doi: 10.1186/s12985-016-0544-0.

[31] M. G. Hemida et al., "Seroepidemiology of Middle East respiratory syndrome (MERS) coronavirus in Saudi Arabia (1993) and Australia (2014) and characterisation of assay specificity," Eurosurveillance, vol. 19, no. 23, p. 20828, 2014, doi: https://doi.org/10.2807/1560-7917.ES2014.19.23.20828.

[32] R Yagil, Camels and camel milk (FAO animal production and health paper 26). Rome, Food and Agriculture Organization of the United Nations, 1982.

[33] Food and Agriculture Organization of the United Nations (FAO)., "FAOSTAT.," FAO, 2012. http://faostat3.fao.org/faostat-gateway/go/to/home/E.

[34] T. A. Aljasim et al., "High Rate of Circulating MERS-CoV in Dromedary Camels at Slaughterhouses in Riyadh, 2019," Viruses, vol. 12, no. 11, p. 1215, Oct. 2020, doi: $10.3390 / v 12111215$.

[35] M. G. Hemida et al., "Dromedary Camels and the Transmission of Middle East Respiratory Syndrome Coronavirus (MERS-CoV)," Transbound. Emerg. Dis., vol. 64, no. 2, pp. 344-353, Apr. 2017, doi: 10.1111/tbed.12401.

[36] M. F. Yusof et al., "Prevalence of Middle East respiratory syndrome coronavirus (MERS-CoV) in dromedary camels in Abu Dhabi Emirate, United Arab Emirates," Virus Genes, vol. 50, no. 3, pp. 509-513, Jun. 2015, doi: 10.1007/s11262-015-1174-0.

[37] C. B. E. M. Reusken et al., "Geographic Distribution of MERS Coronavirus among Dromedary Camels, Africa," Emerg. Infect. Dis., vol. 20, no. 8, pp. 1370-1374, Aug. 2014, doi: 10.3201/eid2008.140590.

[38] D. Falzarano et al., "Dromedary camels in northern Mali have high seropositivity to MERS-CoV," One Heal., vol. 3, pp. 41-43, Jun. 2017, doi: 10.1016/j.onehlt.2017.03.003.

[39] A. Zohaib et al., "Countrywide Survey for MERS-Coronavirus Antibodies in Dromedaries and Humans in Pakistan," Virol. Sin., vol. 33, no. 5, pp. 410-417, Oct. 2018, doi: 10.1007/s12250-018-0051-0.

[40] S. L. Deem et al., "Correction: Serological Evidence of MERS-CoV Antibodies in Dromedary Camels (Camelus dromedaries) in Laikipia County, Kenya," PLoS One, vol. 12, no. 5, p. e0178310, May 2017, doi: 10.1371/journal.pone.0178310. 
[41] Z. M. Al Hammadi et al., "Asymptomatic MERS-CoV Infection in Humans Possibly Linked to Infected Dromedaries Imported from Oman to United Arab Emirates, May 2015," Emerg. Infect. Dis., vol. 21, no. 12, pp. 2197-2200, Dec. 2015, doi: 10.3201/eid2112.151132.

[42] S. Al Muhairi et al., "Epidemiological investigation of Middle East respiratory syndrome coronavirus in dromedary camel farms linked with human infection in Abu Dhabi Emirate, United Arab Emirates," Virus Genes, vol. 52, no. 6, pp. 848-854, Dec. 2016, doi: 10.1007/s11262-016-1367-1.

[43] M. F. Yusof et al., "Diversity of Middle East respiratory syndrome coronaviruses in 109 dromedary camels based on full-genome sequencing, Abu Dhabi, United Arab Emirates," Emerg. Microbes Infect., vol. 6, no. 1, pp. 1-10, Jan. 2017, doi: 10.1038/emi.2017.89.

\section{Figures}

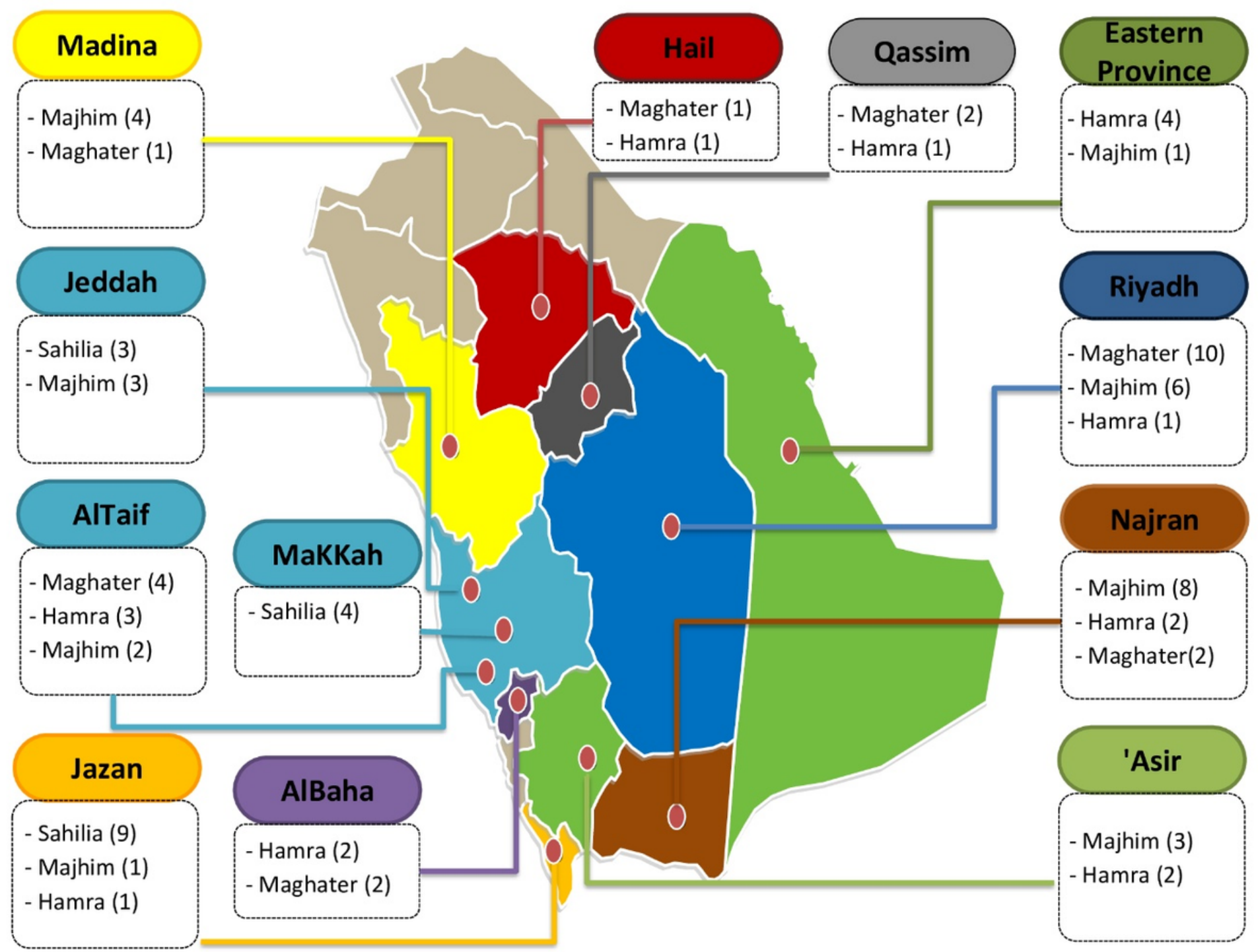




\section{Figure 1}

Sample collection sites in Saudi Arabia highlighting different cities and breeds of camels.
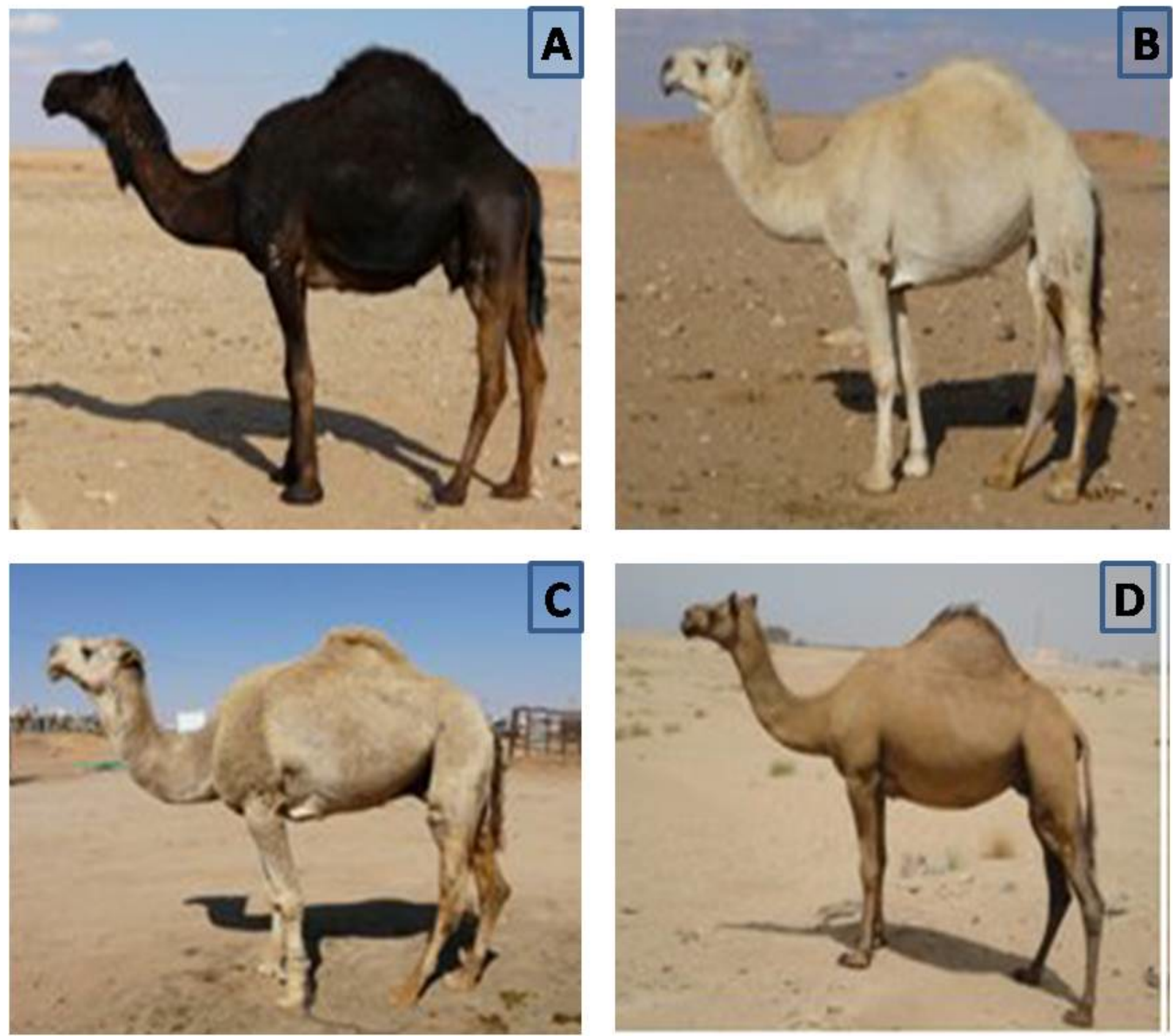

\section{Figure 2}

Four selected camel breeds for sample collection. (A) Majhim (Majaheem or Malah), (B) Maghater (or Waddah), (C) Hamra (or Homor) and (D) Sahilia (or Saheli). 


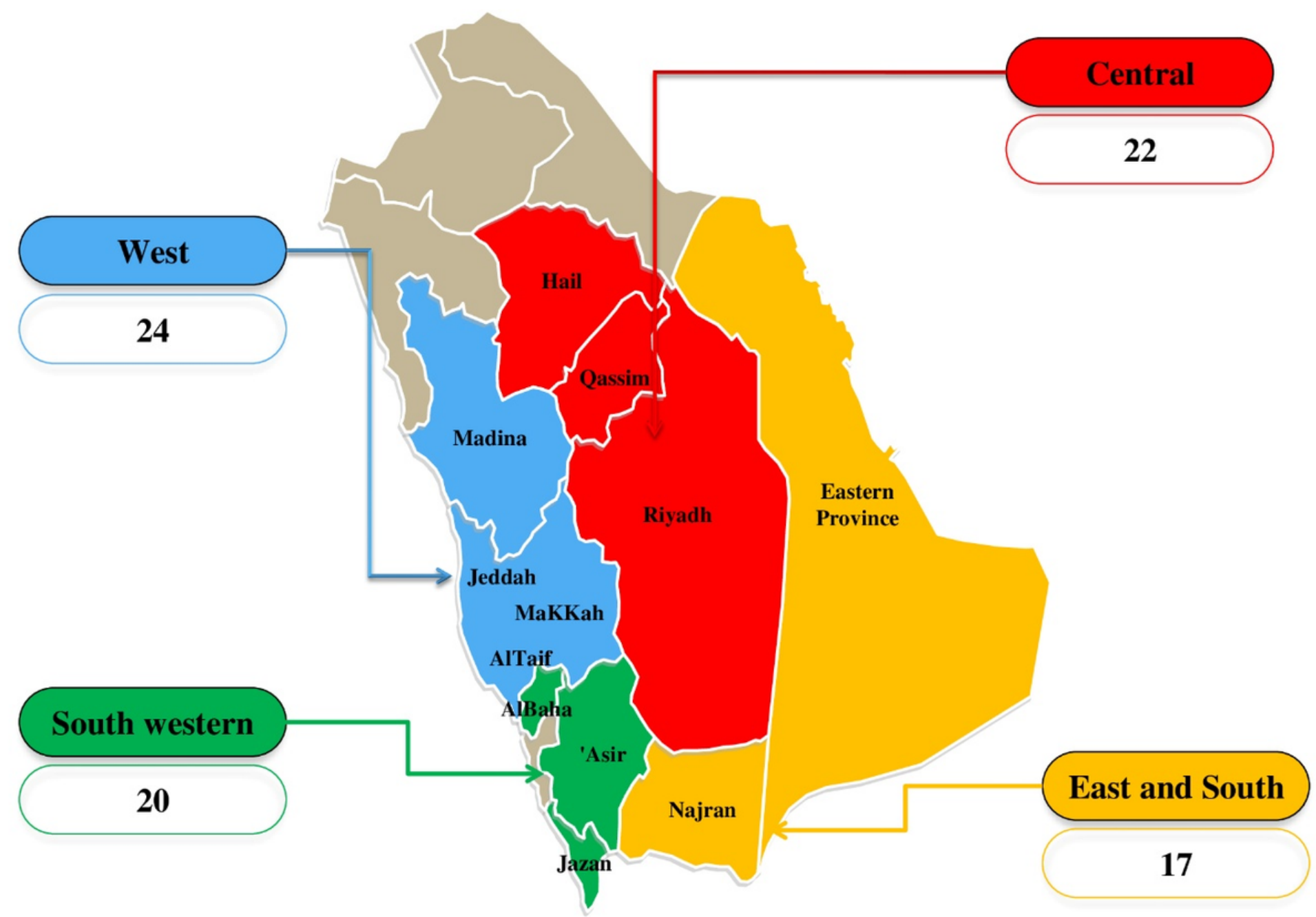

Figure 3

Locations of camel milk samples examined for MERS-CoV from different regions of Saudi Arabia. Total number of camel milk samples collected from each region is indicated. 